\section{PhDepression: Examining How Graduate Research and Teaching Affect Depression in Life Sciences PhD Students}

Logan E. Gin, ${ }^{+\neq}$Nicholas J. Wiesenthal, ${ }^{+\neq}$Isabella Ferreira, ${ }^{\S}$ and Katelyn M. Cooper ${ }^{\dagger *}$ ${ }^{\dagger}$ Research for Inclusive STEM Education Center, School of Life Sciences, Arizona State University, Tempe, AZ 85281; \$Department of Biology, University of Central Florida, Orlando, FL 32816

\begin{abstract}
Graduate students are more than six times as likely to experience depression compared with the general population. However, few studies have examined how graduate school specifically affects depression. In this qualitative interview study of 50 life sciences PhD students from 28 institutions, we examined how research and teaching affect depression in PhD students and how depression in turn affects students' experiences teaching and researching. Using inductive coding, we identified factors that either positively or negatively affected student depression. Graduate students more commonly mentioned factors related to research that negatively affected their depression and factors related to teaching that positively affected their depression. We identified four overarching aspects of graduate school that influenced student depression: the amount of structure in teaching and research, positive and negative reinforcement, success and failure, and social support and isolation. Graduate students reported that depression had an exclusively negative effect on their research, primarily hindering their motivation and self-confidence, but that it helped them to be more compassionate teachers. This work pinpoints specific aspects of graduate school that PhD programs can target to improve mental health among life sciences graduate students.
\end{abstract}

\section{INTRODUCTION}

In 2018, researchers found that graduate students were more than six times as likely to report experiencing depression and anxiety compared with the general population and subsequently declared a "graduate student mental health crisis" (Evans et al., 2018; Flaherty, 2018). Calls to identify which factors exacerbate graduate student mental health problems followed ("The Mental Health of PhD Researchers," 2019; Woolston, 2019a). However, few studies have taken an inductive approach to identifying what aspects of graduate school in particular affect student mental health. More commonly, large quantitative studies propose a limited number of factors that may affect student mental health that participants select from, few of which directly relate to graduate research or teaching (Peluso et al., 2011; Levecque et al., 2017; Evans et al., 2018; Liu et al., 2019). In this interview study, we focus on depression in life sciences PhD students and examine which specific aspects of research and teaching graduate students report as affecting their depression. We also explore how depression affects students' experiences in graduate school.

The American Psychiatric Association defines depression as a common and serious medical illness that negatively affects how one feels, the way one thinks, and how one acts (American Psychiatric Association, 2020). Depression is characterized by nine symptoms: depressed mood; markedly diminished interest or pleasure in activities; reduced ability to think or concentrate, or indecisiveness; feelings of worthlessness, or excessive or inappropriate guilt; recurrent thoughts of death or suicidal ideation, or suicide attempts or plans; insomnia or hypersomnia; significant change in appetite or weight; psychomotor agitation or retardation; and fatigue or
Grant Ean Gardner, Monitoring Editor Submitted Mar 29, 2021; Revised May 7, 2021; Accepted May 14, 2021

CBE Life Sci Educ September 1, 2021 20:ar41

DOI:10.1187/cbe.21-03-0077

tThese authors contributed equally.

*Address correspondence to: Katelyn M. Cooper (Katelyn.Cooper@asu.edu).

(c) 2021 L. E. Gin, N. J. Wiesenthal, et al. CBE-Life Sciences Education ๑ 2021 The American Society for Cell Biology. This article is distributed by The American Society for Cell Biology under license from the author(s). It is available to the public under an Attribution-Noncommercial-Share Alike 3.0 Unported Creative Commons License (http://creativecommons.org/licenses/ by-nc-sa/3.0).

"ASCB®" and "The American Society for Cell Biology $\circledast "$ are registered trademarks of The American Society for Cell Biology. 
loss of energy (American Psychiatric Association, 2013; Schmidt and Tolentino, 2018). For depression to be diagnosed, the presence of at least five of the symptoms is required most of the day, nearly every day, for at least 2 weeks in addition to the occurrence of either depressed mood or diminished interest or pleasure (American Psychiatric Association, 2013). In the general U.S. population, depression affects approximately $6.7 \%$ of individuals and is estimated to affect $16.6 \%$ of individuals at some point in their lifetime.

Graduate students are far more likely to report experiencing depression compared with the general population (Evans et al., 2018; Barreira et al., 2020). Specifically, a recent study of master's and PhD students in programs across the world, spanning a variety of disciplines, found that $39 \%$ of graduate students reported having moderate to severe depression (Evans et al., 2018). Similar studies have demonstrated high rates of depression in graduate students in specific disciplines such as economics (Barreira et al., 2020), biochemistry (Helmers et al., 1997), pharmacology (Helmers et al., 1997), and physiology (Helmers et al., 1997). Depression rates have surged in recent years among graduate students (American College Health Association, 2014, 2019). Talking about depression has become more socially acceptable, particularly among younger adults (Anxiety and Depression Association of America, 2015; Lipson et al., 2019), which may have contributed to the number of students willing to reveal that they are struggling with mental health. Additionally, depression is highly related to burnout, defined as a work-related chronic stress syndrome involving emotional exhaustion, depersonalization, and reduced personal accomplishment (Maslach et al., 2001; Bianchi et al., 2014). Graduate work environments appear to be increasingly characterized as stressful and demanding (American College Health Association, 2014, 2019; Woolston, 2017), which may also be contributing to the increase in graduate depression rates.

Increasingly, scientists, psychologists, and education researchers are recognizing graduate student mental health as a concern and calling for further investigation of graduate student mental health in hopes of identifying interventions to improve graduate student quality of life ("The Mental Health of PhD Researchers," 2019; Woolston, 2019a,b). For example, in 2019, Nature added a question to its annual survey of $\mathrm{PhD}$ students asking students from around the world whether they had sought help for anxiety or depression, and more than one-third (36\%) confirmed they had (Woolston, 2019b). Additionally, notable publication outlets such as Nature ("The Mental Health of PhD Researchers," 2019), Scientific American (Puri, 2019), and Science (Pain, 2018) have published blogs or editorials spotlighting the need to improve graduate student mental health.

Some recent studies have sought to uncover the factors affecting depression in graduate students. Primarily, survey studies with predetermined factors that researchers hypothesized impact student mental health have identified poor mentor-mentee relationships (Peluso et al., 2011; Evans et al., 2018; Hish et al., 2019; Liu et al., 2019; Charles et al., 2021), financial stress (Hish et al., 2019; Jones-White et al., 2020; Charles et al., 2021), and lack of work-life balance (Evans et al., 2018; Liu et al., 2019) to be associated with depression or depressive symptoms among graduate students in various disciplines. Other variables shown to be predictive of depression include low research self-efficacy, defined as low confidence in one's ability to do research (Liu et al., 2019), difficulty publishing papers (Liu et al., 2019), hours worked per week (Peluso et al., 2011), and perceived institutional discrimination (Charles et al., 2021). Factors that appear to be protective of depressive symptoms include social support (Charles et al., 2021), mastery, defined as the extent to which individuals perceive themselves to be in control of the forces that impact their lives (Hish et al., 2019), positive departmental social climate (Charles et al., 2021), optimism about career prospects (Charles et al., 2021), and sense of belonging to one's graduate program (Jones-White et al., 2020). While these studies have identified some depression-related factors associated with graduate school broadly and emphasize the importance of positive mentor-mentee relationships, few studies have explored factors specifically associated with research and teaching, the two activities that graduate students engage in most frequently during their time in a program. Additionally, the extant literature has primarily focused on surface causes of graduate student depression, yet understanding the underlying causes may be key to developing meaningful interventions. For example, while it is well established that student perception of poor mentorship is related to student depression (Evans et al., 2018; Hish et al., 2019; Liu et al., 2019; Charles et al., 2021), it is less well understood what specific behaviors mentors exhibit and how such behaviors negatively affect the cognitive and behavioral underpinnings of graduate student depression. Without this knowledge, it is difficult to develop strategies to help mentors be more inclusive of students.

Theories of depression seek to explain the causes of depression. No theoretical model is widely accepted as an overarching framework for depression within the psychological and psychiatric communities (Mcleod, 2015; Ramnerö et al., 2016); instead, there are a number of models addressing how different aspects of depression are associated with the disorder. Arguably, the three most prominent models are cognitive (Beck et al., 1979), behavioral (Martell et al., 2001), and psychodynamic (Busch et al., 2016). In brief, cognitive theories focus on an individual's beliefs and propose that changes in thinking precede depressive symptoms; for example, negative views of oneself, the world, and the future are thought to be common for individuals with depression (Beck et al., 1979; Leahy, 2002). Behavioral theories emphasize that depression is a result of one's interaction with the environment; depressive symptoms are thought to be the result of decreased reward, lack of positive reinforcement, encouragement of depressive or passive behaviors, and discouragement of healthy behaviors (Lewinsohn, 1974; Martell et al., 2001; Carvalho et al., 2011). Psychodynamic theories of depression consider the role of feelings and behaviors in the etiology and persistence of depressive symptoms; these theories often focus on 1) one's biology and temperamental vulnerabilities, 2) earliest attachment relationships, and 3) childhood experiences associated with frustration, helplessness, loss, guilty, or loneliness (Busch et al., 2016). While each group of theories has been critiqued and no one theory fully explains one's experience with depression (Mcleod, 2015; Ramnerö et al., 2016), we propose that each may be helpful in understanding how aspects of graduate school may affect depression among PhD students.

The thoughts and behaviors associated with depression may in turn affect students' experiences in graduate school, particularly their experiences with research and teaching. While no 
studies have examined how depression explicitly affects graduate students' research experiences, studies have identified ways in which depression can affect students' experiences in undergraduate research (Cooper et al., 2020a,b). Undergraduate researchers report that their depression negatively affected their motivation, ability to concentrate and remember, intellectual engagement, and creativity in research (Cooper et al., 2020b). Undergraduates described that their depression also caused them to be overly self-critical, less social, and ultimately negatively affected their research productivity. Additionally, undergraduates have been reluctant to share their depression with others in the lab, because they fear that they will be judged (Cooper et al., 2020b). While these studies provide some insight into how depression may affect graduate students' experience in research, there is much less information about how depression may affect graduate teaching.

In this study, we interviewed $50 \mathrm{PhD}$ students in the life sciences who self-identified with having depression with the intent of answering two research questions that address gaps in the literature: 1) What specific aspects of graduate research and teaching affect PhD student depression? 2) How does PhD students' depression affect their experience in research and teaching?

\section{METHODS}

\section{Student Interviews}

This study was done under an approved Arizona State University Institutional Review Board protocol (no. 00011040).

In Fall 2019, we surveyed graduate students by sending an email out to program administrators of all life sciences graduate programs in the United States that are listed in U.S. News \& World Report (2019). Of the 259 graduate programs that we contacted, 75 (29.0\%) program administrators agreed to forward our survey to students enrolled in their graduate programs. Of the 840 graduate students who participated in the survey, 459 (54.6\%) self-identified as having depression based on general demographic questions on the survey. Of the 459 students who identified as having depression, $327(71.2 \%)$ agreed to be contacted for a follow-up interview. In Summer 2020, we sent a recruitment email out to the 327 students who identified as having depression, asking to interview them about their experiences with depression in a $\mathrm{PhD}$ program. We specifically did not require that students be diagnosed with depression in order to participate in the interview study. We did not want to bias our sample, as mental health care is disproportionately unavailable to Black and Latinx individuals, as well as to those who come from low socioeconomic backgrounds (Howell and McFeeters, 2008; Kataoka et al., 2002; Santiago et al., 2013). Of the students who were contacted, $50 \mathrm{PhD}$ students (15.3\%) enrolled across 28 life sciences $\mathrm{PhD}$ programs completed an interview.

The interview script was based on a previous interview script that we had developed, which successfully elicited what aspects of research affect depression in undergraduates and how depression affects their research (Cooper et al., 2020a). Our previous work has shown that research experiences do not exclusively worsen depression, but that aspects of research can also help students manage their depression (Cooper et al., 2020a). As such, our interview questions explored what aspects of research helped students manage their depression (positively affecting depression), and what aspects worsened students' depression (negatively affecting depression). Additionally, we hypothesized that other prominent aspects of graduate school, such as teaching, would also affect $\mathrm{PhD}$ student depression and revised the interview script to include questions focused on examining the relationship between depression and teaching. We asked students what aspects of graduate research and teaching made their depression worse and what aspects helped them manage their depression. Participants were invited to come up with as many aspects as possible. We also asked how students perceived their depression affected their research and teaching. With the knowledge that we would be conducting interviews during summer of 2020 in the midst of the COVID-19 pandemic, and that the pandemic had likely exacerbated graduate student depression (Chirikov et al., 2020), we directed students to not reference aspects of research and teaching that were uniquely related to the pandemic (e.g., teaching remotely or halted research) when discussing the relationship between research, teaching, and depression. We were specifically interested in aspects of teaching and research that affected student depression before the pandemic and would presumably affect student depression afterward. We conducted think-aloud interviews with four graduate students who identified as having depression to ensure that our questions would not offend anyone with depression and to establish cognitive validity of the interview script by ensuring that each student understood what each question was asking. The interview script was iteratively revised after each think-aloud interview (Trenor et al., 2011). A final copy of the interview script can be found in the Supplemental Material.

All interviews were conducted using Zoom by one of two researchers (L.E.G. or K.M.C.). The average interview time was about 45 minutes. After the interview, all participants were sent a short survey to collect their demographics and additional information about their depression (a copy of the survey can be found in the Supplemental Material). Participants were provided a small monetary gift card in exchange for their time. All interviews were deidentified and transcribed before analysis.

\section{Interview Analysis}

Three researchers (L.E.G., N.J.W., and K.M.C.) independently reviewed 12 of the same randomly selected interviews to explore each idea that a participant expressed and to identify recurring themes (Charmaz, 2006). Each researcher took detailed analytic notes during the review. After, the three researchers met to discuss their notes and to identify an initial set of recurring themes that occurred throughout the interviews (Saldaña, 2015). The authors created an initial codebook outlining each theme and the related description. Together, the authors then reviewed the same set of five additional interviews to validate the themes outlined in the codebook and to identify any themes that may have been missed during the initial review. The researchers used constant comparison methods to compare quotes from the interviews to each theme and to establish whether any quotes were different enough from a particular theme to warrant an additional code (Glesne and Peshkin, 1992). Together, the three researchers revised the codebook until they were confident that it captured the most common themes and that no new themes were emerging. A final copy of the codebook can be found in the Supplemental Material. Two authors (L.E.G. and N.J.W.) used the final codebook to code five randomly selected interviews (10\% of all interviews) and their 
Cohen's $\kappa$ interrater score was at an acceptable level $(\kappa=0.94$; Landis and Koch, 1977). Then, one researcher (N.J.W.) coded the remaining 45 interviews. In the text, we present themes mentioned by at least $10 \%$ of interviewees and use quotes to highlight themes. Some quotes were lightly edited for clarity.

\section{Author Positionality}

Some of the authors identify as having depression and some do not. One author had completed a PhD program (K.M.C.), one author was in the process of completing a PhD program (L.E.G.), and two authors were undergraduates (N.J.W. and I.F.) at the time when the interviews and analyses took place.

\section{Interview Participants}

Fifty $\mathrm{PhD}$ students agreed to participate in the study. Students were primarily women (58\%), white $(74 \%)$, and continuing-generation college students $(78 \%)$. Twelve percent of students were international students, and the average age of the participants was 28 years old. While $20 \%$ of students were unsure of their career goals, $32 \%$ of students planned to pursue a career in academia, and $24 \%$ were planning to pursue a career in industry. Students reported how severe they perceived their depression to be, on average, during the time they had spent in their $\mathrm{PhD}$ programs. Most students reported their depression as either moderate $(50 \%)$ or severe (28\%). Eighty percent of students reported being diagnosed with depression, and 74\% reported receiving treatment for depression. Participants were at different stages in their $\mathrm{PhD}$ programs ranging from first year to sixth year or more. Three students had graduated between the time they completed the initial survey and when they participated in the interview in Summer 2020. Students self-reported their main research areas and represented a broad range, with ecology and evolutionary biology (26\%), animal science (14\%), molecular biology (14\%), and neurobiology (10\%) being the most common. Eighty-six percent of students had experience teaching undergraduates, primarily as teaching assistants (TAs), at the time of the interviews. All student demographics are summarized in Table 1.

\section{RESULTS}

\section{The Effect of Research on Graduate Student Depression}

Students more commonly identified ways that research negatively affected their depression than ways research positively affected their depression. Considering all factors that students listed and not just those that were most common, students on average listed two ways in which an aspect of research negatively affected their depression and one way in which an aspect of research positively affected their depression.

The most commonly reported aspect of research that worsened students' depression was experiencing failures, obstacles, or setbacks in research. Specifically, students cited that failed experiments, failed research projects, and the rejection of manuscripts and grants was particularly difficult for their depression. Conversely, students highlighted that their depression was positively affected when they were able to make substantial progress on their research projects; for example, if they wrote part of a manuscript or if an experiment worked. Students also explained that accomplishing smaller or mundane research tasks was helpful for their depression, both because they felt as though they were checking off a box and also because it allowed them to focus on something other than the negative thoughts often associated with depression.

Students also highlighted that the unstructured nature of graduate research worsened their depression. Specifically, students described that, in graduate research, there are often no clear directions, sets of guidelines, or deadlines to help structure their day-to-day activities. Without this structure, students need to rely on their own motivation to outline goals, accomplish tasks, or seek help, which participants described can be difficult when one is experiencing a depressive episode. However, students also felt as though the unstructured nature of research benefited their depression, because it allowed for flexibility. Those who did not have frequent deadlines or strict schedules were able to not conduct research on days when they needed to recover from a depressive episode or schedule research around therapy or other activities that had a positive impact on their depression. Finally, students highlighted that their passion for their research was protective against depression. Their love for the subject of their research or thinking about how their work may have a positive impact on others could positively affect their motivation or mood.

Students described that their relationships with others in the lab also affected their depression. Specifically, if their mentors or others in their lab had unreasonable or overwhelming expectations of them, it could make them feel as though they would never be able to meet such expectations. Research also provides an environment for students to constantly compare themselves with others, both those in supervisory roles as well as peers. Notably, when students mentioned comparing themselves with others, this comparison never made them feel good about themselves, but was exclusively detrimental to their depression; they felt as though they would never be able to accomplish what others had already accomplished. Students' relationships with their mentors also seemed to have a notable impact on their depression. Having a positive relationship with their mentors or a mentor who provided psychosocial support positively affected their depression, whereas perceiving a negative relationship with their mentors, particularly a mentor who provided consistently harsh or negative feedback, was detrimental. Students who had absent mentors or mentors who provided infrequent technical support and guidance also felt as though this situation worsened their depression, because it prevented or prolonged their success in research. Finally, students highlighted that conducting graduate research can be isolating, because you are often working on something different from those in the lab or because those outside graduate school cannot relate to the stress and struggles associated with research. However, in instances in which students were able to collaborate with others, this could be protective against depression, because it gave students a sense of comradery or validated their feelings about specific aspects of research. The most common research-related factors that students reported negatively and positively affected their depression and example student quotes of each factor are reported in Tables 2 and 3, respectively.

\section{The Effect of Teaching on Graduate Student Depression}

We asked all graduate students who had teaching experience $(n=43)$ how teaching affected their depression. Graduate students more commonly identified ways that teaching positively affected their depression than ways teaching negatively 


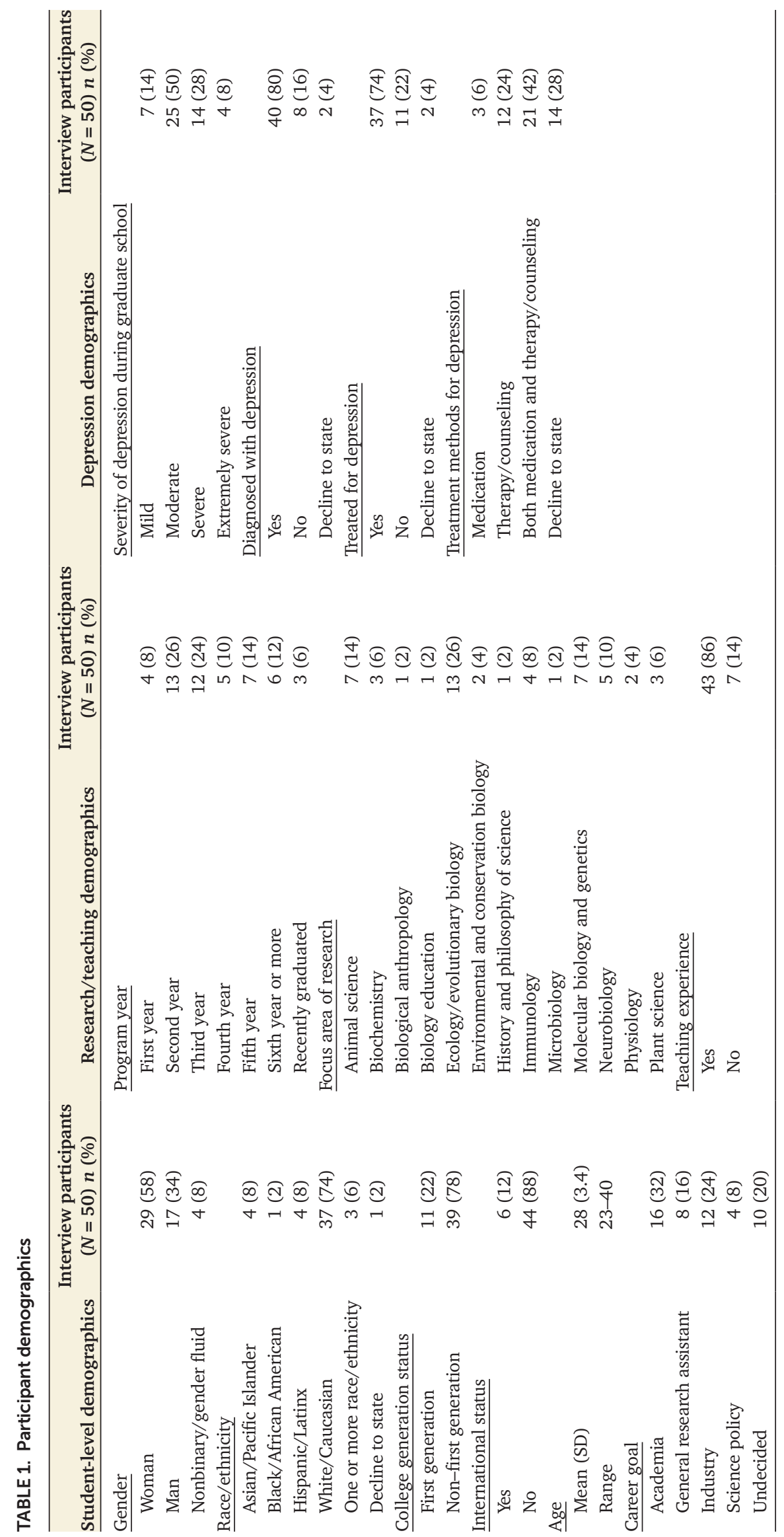


TABLE 2. Research-related factors that PhD students reported negatively affected their depression

\begin{tabular}{|c|c|c|c|c|}
\hline Factor & Description & $\begin{array}{c}\%(n) \\
(N=50)\end{array}$ & Example quote & Example quote \\
\hline $\begin{array}{l}\text { Failures, obstacles, or } \\
\text { setbacks during } \\
\text { research }\end{array}$ & $\begin{array}{l}\text { Experiencing failure, } \\
\text { obstacles, or setbacks in } \\
\text { graduate school can } \\
\text { negatively affect student } \\
\text { depression. This } \\
\text { commonly includes } \\
\text { experiencing failed exper- }\end{array}$ & $48(24)$ & $\begin{array}{l}\text { Student 20: "Everything just fails } \\
\text { and you have zero positive } \\
\text { results and nothing you can } \\
\text { publish. That was one of the } \\
\text { worst things for me. The } \\
\text { stress of knowing that you are } \\
\text { not succeeding is really bad }\end{array}$ & $\begin{array}{l}\text { Student 5: "I could do everything } \\
\text { perfectly and for one reason or } \\
\text { another the whole project could } \\
\text { just fail. So, I think the } \\
\text { breakdown of that link between } \\
\text { my actions and the outcome, } \\
\text { that was hard." }\end{array}$ \\
\hline
\end{tabular}

Unstructured research experiences

Negative reinforcement

Unreasonable or overwhelming expectations

Opportunity to compare self to others
Negative reinforcement from others in research such as harsh criticism, feedback, comments, or reviews about one's research or performance can negatively affect student depression.

Mentors or others in research who place too high of expectations on students, particularly related to the progress that they are making in research, can negatively affect student depression.

34 (17) Student 26: "[Your mentor] will tell you how poorly you're doing to inspire you to work harder, and that's not something that works with me, because I already see everything that I'm doing wrong, and all the problems in a project, so I don't need a mentor that points out those problems to me again, because I'm like, 'Yeah, I [expletive] know all the problems! I should just quit, right?"'

34 (17) Student 4: "My [previous] advisor had really high expectations and was really pushy. It really exacerbated my depression a lot, because I felt like I could never live up to the expectations."

When students compare their success in research to others' success, it can negatively affect their depression.

Student 24: "I think that I'm a huge person that compares themselves to others. When I hear others speak about their research or their progress, though it may not be light years away from mine, it feels that way. I get sad. I feel like I'm not where I'm supposed to be or that I don't deserve to be where I'm at compared to others."
Student 12: "For me, I think the periods of time post-classes were a lot harder in terms of mental health, where there aren't as many external deadlines. You're mostly driven by your own goals and ambitions every day. (...) But when [goals and ambitions] are dropped, it's really easy for depression to kick in."

Student 7: "You say something stupid and your PI (principal investigator) suddenly says how stupid that is. And then all that just [makes me think] 'I'm an idiot, I can't do it."'

Student 29: "I think when I'm working hard and where my hours are going doesn't necessarily make sense to my advisor [it affects my depression]. I'm like, 'No, I'm working, I'm working, I'm working.' And then they're like, 'Well, but maybe work harder.' That feels pretty bad."

Student 44: "Sometimes I see my other cohort students succeeding and not even in a jealous way necessarily, but I do measure myself against them. If I haven't gotten my first author publication yet or whatever, that means I'm behind the curve. I think part of [my depression] is just comparing myself to others." 
TABLE 2. Continued

\begin{tabular}{|c|c|c|c|c|}
\hline Factor & Description & $\begin{array}{c}\%(n) \\
(N=50)\end{array}$ & Example quote & Example quote \\
\hline $\begin{array}{l}\text { Lack of technical } \\
\text { support or guidance }\end{array}$ & $\begin{array}{l}\text { Not receiving adequate } \\
\text { support or guidance in } \\
\text { research can negatively } \\
\text { affect student depression. }\end{array}$ & $22(11)$ & $\begin{array}{l}\text { Student 18: "I've experienced my } \\
\text { PI being very absent. And so, } \\
\text { not having that touchstone of } \\
\text { advice like, 'Stop now, maybe } \\
\text { stop while you're ahead, or } \\
\text { maybe you can change this,' } \\
\text { and then wasting all that time } \\
\text { or feeling like I've wasted all } \\
\text { that time can make it harder } \\
\text { [on my depression]." }\end{array}$ & $\begin{array}{l}\text { Student 49: "You get thrown in the } \\
\text { deep end on projects, and the } \\
\text { lab has been so busy that there's } \\
\text { been no support. So, if you fall a } \\
\text { little flat, then it's just all on you } \\
\text { where they're like, 'Oh man, I } \\
\text { wish I could help you out with } \\
\text { that or give you this support,' } \\
\text { and I feel like I've been set up to } \\
\text { fail a lot." }\end{array}$ \\
\hline Social isolation & $\begin{array}{l}\text { Feeling isolated when doing } \\
\text { research, either because } \\
\text { others in the lab or others } \\
\text { outside graduate school } \\
\text { cannot relate to specific } \\
\text { stressors and experiences, } \\
\text { can negatively affect } \\
\text { student depression. }\end{array}$ & 18 (9) & $\begin{array}{l}\text { Student 8: “[Doing research] is } \\
\text { very isolating because } \\
\text { obviously not many people go } \\
\text { for PhDs. I can't talk to [my } \\
\text { friends] about research } \\
\text { struggles because they're like, } \\
\text { 'OK, how do I fix that? You } \\
\text { did that to yourself.' And I'm } \\
\text { like, 'I mean, you're right, } \\
\text { but...' Nobody understands } \\
\text { you." }\end{array}$ & $\begin{array}{l}\text { Student 20: "I think that's one thing } \\
\text { [that affects my depression], } \\
\text { when it comes to research, it's } \\
\text { quite a lonely experience } \\
\text { sometimes when you're working } \\
\text { on your own project and } \\
\text { everybody else has their own } \\
\text { project. They have their own } \\
\text { worries to think about and all } \\
\text { you are stressing about is your } \\
\text { own thing." }\end{array}$ \\
\hline
\end{tabular}

affected their depression. On average, considering all factors that graduate students listed and not just those that were most common, participants listed two ways in which teaching positively affected their depression and one way in which teaching negatively affected their depression.

Graduate students most commonly highlighted that teaching provided positive reinforcement from undergraduates, which helped them manage their depression. This positive reinforcement came in multiple forms ranging from formal teaching evaluations to positive verbal comments from undergraduates about how good a graduate student was at teaching to watching undergraduates accomplish academic goals or grasp complex concepts. A subset of graduate students highlighted that teaching was good for their depression, because it was something they were passionate about or that they genuinely enjoyed. As such, it was a source of happiness, as was being able to collaborate and form friendships with other TAs or instructors. Some graduate students also acknowledged that they felt confident teaching, often because they had mastered content that undergraduates had not. However, this was not always the case; some graduate students highlighted that a lack of teaching training and preparation negatively affected their self-efficacy as instructors, which in turn exacerbated their depression. This was further exacerbated by the pressure that graduate students put on themselves to perform well as instructors. The potential to have a negative impact on undergraduates and their learning experiences could worsen students' depression by increasing the stress surrounding their performance as a teacher. Additionally, some graduate students received negative reinforcement from undergraduates, in the form of negative comments on formal teaching evaluations or disrespectful behavior from undergraduates such as groans or eye rolls, which graduate students explained negatively affected their self-efficacy, further worsening their depression.
Students also highlighted that teaching could negatively affect their depression because it interfered with the time they felt they needed to be spending on research or added to the large number of responsibilities they had as graduate students. However, some students welcomed time away from research; teaching sometimes served as a distraction from research-related stressors. Students also highlighted that teaching is structured, which positively affected their depression. That is, there are concrete tasks, such as grading, that need to be accomplished or places that the graduate student needs to be during a specific time. This structure helped motivate them to accomplish teaching goals, even if they were feeling a lack of motivation because of their depression. The most common teaching-related factors that graduate students reported negatively and positively affected their depression and example student quotes for each factor are reported in Tables 4 and 5, respectively.

\section{The Effect of Depression on Graduate Research}

In the interviews, we asked graduate students how their depression affected their graduate research, if at all. They identified three primary ways in which depression could affect research, all of which were negative. The most common way depression affected research was interfering with students' motivation, which in turn affected their productivity. Students described that their productivity was affected immediately, for example, struggling to execute daily tasks like collecting or analyzing data. However, graduate students described that their lack of motivation ultimately resulted in larger consequences, such as delays in getting papers submitted and published. In fact, some graduate students explicitly stated that they felt as though they would have been able to graduate earlier if they had not had depression. The second way in which depression affected graduate students' research is that it interfered with their ability to 
TABLE 3. Research-related factors that PhD students reported positively affected their depression

\begin{tabular}{|c|c|c|c|c|}
\hline Factor & Description & $\%(n)(N=50)$ & Example quote & Example quote \\
\hline $\begin{array}{l}\text { Completing small or } \\
\text { concrete research } \\
\text { tasks }\end{array}$ & $\begin{array}{l}\text { Completing small or } \\
\text { concrete research tasks } \\
\text { helps students feel like } \\
\text { they have accomplished } \\
\text { something or distracts } \\
\text { their mind from } \\
\text { negative thoughts, } \\
\text { which can positively } \\
\text { affect student depres- } \\
\text { sion. }\end{array}$ & $26(13)$ & $\begin{array}{l}\text { Student 24: "When I'm doing wet } \\
\text { lab work I'm in the zone, [it is } \\
\text { good for my depression]. When } \\
\text { I'm in that mode, it doesn't } \\
\text { allow me to be depressed, } \\
\text { because I'm too busy to really } \\
\text { overthink things." }\end{array}$ & $\begin{array}{l}\text { Student 35: "I have a very simple } \\
\text { goal, which is to collect my data } \\
\text { and that's all I think about for } \\
\text { the entire day. I'm hiking, I'm } \\
\text { listening to audio books, } \\
\text { whatever. And so, there's } \\
\text { literally just no time for me to } \\
\text { get caught up in my own mind." }\end{array}$ \\
\hline Working with others & $\begin{array}{l}\text { Interacting with others can } \\
\text { positively affect student } \\
\text { depression. }\end{array}$ & $22(11)$ & $\begin{array}{l}\text { Student 43: "Working collabora- } \\
\text { tively with other students and } \\
\text { working consistently with } \\
\text { faculty helps a lot [with my } \\
\text { depression]." }\end{array}$ & $\begin{array}{l}\text { Student 20: "Friends, obviously, } \\
\text { colleagues, people who share } \\
\text { the same sentiment [help my } \\
\text { depression]. It's amazing to have } \\
\text { people right next to you say, } \\
\text { 'Don't worry about it, this } \\
\text { happens to everyone. Try this, } \\
\text { try that." }\end{array}$ \\
\hline $\begin{array}{l}\text { Passionate about } \\
\text { research topic }\end{array}$ & $\begin{array}{l}\text { Feeling passionate about } \\
\text { their research topic or } \\
\text { caring about the } \\
\text { potential impact of } \\
\text { research can positively } \\
\text { affect student depres- } \\
\text { sion. }\end{array}$ & $18(9)$ & $\begin{array}{l}\text { Student 10: "I love vaccines, I love } \\
\text { immunology, I love recombi- } \\
\text { nant genetic engineering. That } \\
\text { in itself actually does help [my } \\
\text { depression] a lot because I get } \\
\text { to learn more every day. (...) } \\
\text { That absolutely helps [my } \\
\text { depression] because it drives } \\
\text { me." }\end{array}$ & $\begin{array}{l}\text { Student 25: "I study plants and I } \\
\text { really love plants and being } \\
\text { around them. And so that's been } \\
\text { the best part is getting to work } \\
\text { with plants in the greenhouse, } \\
\text { and that feels helpful [for my } \\
\text { depression]." }\end{array}$ \\
\hline Flexibility & $\begin{array}{l}\text { Flexibility in research allows } \\
\text { students to feel as } \\
\text { though they have } \\
\text { control over their time } \\
\text { and they can prioritize } \\
\text { their mental health } \\
\text { (e.g., by going to } \\
\text { therapy or taking a men- } \\
\text { tal health day) when } \\
\text { necessary, which can } \\
\text { positively affect student } \\
\text { depression. }\end{array}$ & $18(9)$ & $\begin{array}{l}\text { Student 12: "I can schedule } \\
\text { therapy whenever. I'm not } \\
\text { confined to a specific nine-to- } \\
\text { five workday. (...) If I wake up } \\
\text { one day and I'm really } \\
\text { struggling, I can shift my } \\
\text { weekends. I can be like, 'All } \\
\text { right. Today I need to take care } \\
\text { of me,' and then maybe I'll } \\
\text { work an extra day of the } \\
\text { weekend if I need to catch up } \\
\text { or something. So that flexibility } \\
\text { can be really supportive." }\end{array}$ & $\begin{array}{l}\text { Student 47: "Some jobs, you have } \\
\text { to be there, whereas with grad } \\
\text { school if I'm having a really bad } \\
\text { day and I really feel like I can't } \\
\text { handle being in the lab, it's a } \\
\text { little easier for me to not have to } \\
\text { be there or for me to rearrange } \\
\text { my schedule so I'm doing [tasks] } \\
\text { that are a little bit less stressful } \\
\text { for me." }\end{array}$ \\
\hline Research progress & $\begin{array}{l}\text { Making significant progress } \\
\text { in research can } \\
\text { positively affect student } \\
\text { depression. }\end{array}$ & $16(8)$ & $\begin{array}{l}\text { Student 46: "I will say [something } \\
\text { that helps my depression] is } \\
\text { when you are working really } \\
\text { hard on the experiment, on the } \\
\text { goal, and then finally you get } \\
\text { something, when you get good } \\
\text { data. This makes all of my } \\
\text { effort worth it." }\end{array}$ & $\begin{array}{l}\text { Student 1: "Making progress helps } \\
\text { me feel less [depressed], when I } \\
\text { am getting a lot of data. I never } \\
\text { feel stressed about my produc- } \\
\text { tivity at those points in time." }\end{array}$ \\
\hline $\begin{array}{l}\text { Emotionally } \\
\text { supportive PI }\end{array}$ & $\begin{array}{l}\text { A positive mentor } \\
\text { relationship, which } \\
\text { often involves psychoso- } \\
\text { cial support, can } \\
\text { positively affect student } \\
\text { depression. }\end{array}$ & $12(6)$ & $\begin{array}{l}\text { Student 23: "Things that help } \\
\text { [my depression] are having a } \\
\text { supportive PI who you're } \\
\text { able to talk to about your } \\
\text { mental illness, and who's } \\
\text { understanding." }\end{array}$ & $\begin{array}{l}\text { Student 38: "If I didn't have the } \\
\text { advisors that I have now, I don't } \\
\text { know that I would be able to } \\
\text { proceed through getting a PhD, } \\
\text { because I have been able to be } \\
\text { very open with them about my } \\
\text { mental health struggles and the } \\
\text { reality of how mental illness } \\
\text { affects me and affects my life } \\
\text { and my productivity. And they } \\
\text { haven't really rigorously } \\
\text { pushed me beyond my stated } \\
\text { limitations." }\end{array}$ \\
\hline
\end{tabular}


TABLE 4. Teaching-related factors that PhD students reported negatively affected their depression

\begin{tabular}{|c|c|c|c|c|}
\hline Factor & Description & $\%(n)(N=43)^{\mathrm{a}}$ & Example quote & Example quote \\
\hline $\begin{array}{l}\text { Increases number of } \\
\text { responsibilities/ } \\
\text { time away from } \\
\text { research }\end{array}$ & $\begin{array}{l}\text { Teaching adds to the total } \\
\text { number of responsibilities } \\
\text { that graduate students } \\
\text { have and can interfere } \\
\text { with the time that they } \\
\text { feel they need to spend on } \\
\text { research, which increases } \\
\text { stress and can negatively } \\
\text { affect student depression. }\end{array}$ & $47(20)$ & $\begin{array}{l}\text { Student 10: "As a PhD student, } \\
\text { you're expected to publish, } \\
\text { do all this research, and } \\
\text { then also teach. A little } \\
\text { while ago, I was both } \\
\text { designing a class and } \\
\text { teaching two sections at the } \\
\text { same time, and I was spend- } \\
\text { ing so much time on that } \\
\text { class. It was close to } 40 \\
\text { hours per week plus } \\
\text { research. I definitely was } \\
\text { feeling overwhelmed, and I } \\
\text { do think that can affect [my } \\
\text { depression], because it } \\
\text { leads to burnout." }\end{array}$ & $\begin{array}{l}\text { Student 12: "Teaching often } \\
\text { regularly leaves you with less } \\
\text { time to focus on research. So, } \\
\text { it is time away from research. } \\
\text { And if I'm already feeling like } \\
\text { I'm not doing enough, having } \\
\text { the extra load of teaching can } \\
\text { just amp that feeling up." }\end{array}$ \\
\hline $\begin{array}{l}\text { Negative reinforcement } \\
\text { from undergradu- } \\
\text { ates }\end{array}$ & $\begin{array}{l}\text { Negative reinforcement from } \\
\text { undergraduates, in the } \\
\text { form of being rude, } \\
\text { disrespectful, or } \\
\text { disengaged, or receiving } \\
\text { negative scores and } \\
\text { comments on teaching } \\
\text { evaluations, can negatively } \\
\text { affect student depression. }\end{array}$ & 28 (12) & $\begin{array}{l}\text { Student 29: "It [is hard for my } \\
\text { depression] and really bums } \\
\text { me out when [the } \\
\text { undergraduates] don't try. I } \\
\text { put a lot into [teaching]. } \\
\text { (...) The ones that are just } \\
\text { like, 'I don't want to do this,' } \\
\text { and roll their eyes, it's just } \\
\text { hard. It's like, I put so much } \\
\text { into making [the content] } \\
\text { clear and I'm trying. So, } \\
\text { when the students are not } \\
\text { really trying, it does not feel } \\
\text { great." }\end{array}$ & $\begin{array}{l}\text { Student 19: I've had students } \\
\text { straight up tell me, 'This is the } \\
\text { least important class that I } \\
\text { have to take this semester. I'm } \\
\text { not going to put in much } \\
\text { effort.' And it makes me feel } \\
\text { kind of crummy, kind of bad. } \\
\text { When at the end of the } \\
\text { semester, I get the teaching } \\
\text { evaluations saying, 'I just took } \\
\text { this class because I need it or I } \\
\text { had to. I didn't think it added } \\
\text { anything to my education.' I } \\
\text { feel very low." }\end{array}$ \\
\hline $\begin{array}{l}\text { Personal pressure to } \\
\text { teach well }\end{array}$ & $\begin{array}{l}\text { Feeling an obligation to teach } \\
\text { undergraduates well or } \\
\text { ensure that they under- } \\
\text { stand the course content } \\
\text { can induce stress } \\
\text { and negatively affect } \\
\text { depression. }\end{array}$ & $26(11)$ & $\begin{array}{l}\text { Student 16: "[My depression } \\
\text { related to teaching] all } \\
\text { comes back to the stress of } \\
\text { having to do a good job for } \\
\text { my students. I didn't want } \\
\text { to fail them. So that was } \\
\text { difficult and I took [being a } \\
\text { teacher] very seriously." }\end{array}$ & $\begin{array}{l}\text { Student 40: "I think feeling like } \\
\text { there were these undergrads } \\
\text { depending on me [negatively } \\
\text { affected by depression]. (...) } \\
\text { If I haven't sufficiently } \\
\text { prepared to lead a discussion } \\
\text { section or whatever, there are } \\
\text { undergrads whose education } \\
\text { will suffer. That added } \\
\text { pressure was hard [on my } \\
\text { depression] and just being } \\
\text { afraid of letting them down." }\end{array}$ \\
\hline $\begin{array}{l}\text { Lack of teaching } \\
\text { training or } \\
\text { guidance }\end{array}$ & $\begin{array}{l}\text { Not having training or } \\
\text { guidance about how to } \\
\text { teach made students feel } \\
\text { insecure about their } \\
\text { teaching abilities, which } \\
\text { can negatively affect their } \\
\text { depression. }\end{array}$ & $16(7)$ & $\begin{array}{l}\text { Student 25: "[My depression } \\
\text { worsened] because I was } \\
\text { concerned about the lack of } \\
\text { supervision and the lack of } \\
\text { support for how to teach. } \\
\text { (...) I just felt like I was } \\
\text { doing a terrible job, which } \\
\text { was really discouraging." }\end{array}$ & $\begin{array}{l}\text { Student 26: "I didn't feel like I } \\
\text { had enough guidance as to } \\
\text { what I should be teaching } \\
\text { [the undergraduates in my } \\
\text { class] and how to control a } \\
\text { classroom, so not having the } \\
\text { respect of the students and } \\
\text { not knowing how to get it was } \\
\text { really stressful." }\end{array}$ \\
\hline
\end{tabular}

${ }^{\mathrm{a} F o r t y-t h r e e ~ o u t ~ o f ~ t h e ~} 50$ students who participated in the study had experience teaching undergraduates either as a TA or as an instructor of record. We only considered the responses from the TAs with teaching experiences when calculating the percent of students who reported each factor.

focus or concentrate. Students primarily explained that the lack of focus did not delay their research but caused their research to be less enjoyable or made them frustrated because they had to expend additional mental energy to execute tasks. Depression also caused students to be less confident or overly critical of themselves. Specifically, if an experiment did not go right or they experienced rejection of a manuscript, they tended to internalize it and blame themselves. This lack of confidence often inhibited students' abilities to make decisions about research or take risks in research. They described frequently second-guessing themselves, which made decisions and taking risks in research more difficult. The most common ways students reported that their depression affected their research and example student quotes are reported in Table 6. 
TABLE 5. Teaching-related factors that PhD students reported positively affected their depression

\begin{tabular}{|c|c|c|c|c|}
\hline Factor & Description & $\%(n)(N=43)^{\mathrm{a}}$ & Example quote & Example quote \\
\hline $\begin{array}{l}\text { Positive reinforcement } \\
\text { from undergraduates }\end{array}$ & $\begin{array}{l}\text { Positive reinforcement from } \\
\text { undergraduates, in the } \\
\text { form of positive verbal } \\
\text { comments, positive com- } \\
\text { ments on formal } \\
\text { evaluations, or watching } \\
\text { undergraduates grasp a } \\
\text { concept or get excited } \\
\text { about content, can } \\
\text { positively affect student } \\
\text { depression. }\end{array}$ & $58(25)$ & $\begin{array}{l}\text { Student 15: "What really helped } \\
\text { me during those depressive } \\
\text { times were that my students } \\
\text { would say like, 'Sulfates in } \\
\text { my shampoo, they're not } \\
\text { good for the water. I learned } \\
\text { that from you."' }\end{array}$ & $\begin{array}{l}\text { Student 5: "Interacting with my } \\
\text { undergraduates and feeling } \\
\text { like I made a difference for } \\
\text { them [helps my depression]. } \\
\text { Even if it was just something as } \\
\text { simple as them saying like, 'Oh, } \\
\text { wow [Student 5], I feel like I } \\
\text { actually really get this now,' or } \\
\text { 'I did better on this exam after } \\
\text { we went over material } \\
\text { together."' }\end{array}$ \\
\hline
\end{tabular}

Teaching as a structured The structured nature of task

Passion for teaching

Distraction from research

\section{Confidence about teaching}

Positive relationships with others teaching
Teaching can serve as a distraction from stressors related to research, which can positively affect student depression.
33 (14) teaching, including having concrete tasks to accomplish and specific places to be at specific times, can positively affect student depression.

$$
\begin{aligned}
& \text { Being passionate about } \\
& \text { teaching and enjoying } \\
& \text { teaching can positively } \\
& \text { affect student depres- } \\
& \text { sion. }
\end{aligned}
$$

Having confidence about teaching, specifically about being a good teacher or having mastery of the content, can positively affect student depression.

Having positive relationships with others involved in teaching, particularly other TAs or a lead instructor, can positively affect student depression.
Student 27: "Sometimes having concrete tasks does [help my depression]. With research, you never have deadlines or things that get accomplished or finished. Where at least with teaching, you can sit down and you can grade for three hours. You can do things."

Student 48: "I've always enjoyed teaching. One main reason I did a $\mathrm{PhD}$ was to teach at the postsecondary level. So, for me, honestly, the experience of interacting with students is energizing, and does rejuvenate me a lot."

Student 42: "Research is tedious and difficult and honestly I have to admit I never really had fun with it. But teaching is kind of a way away from that. It's something that you can still do and you can still contribute like you've got a good job and you're doing things. (...) It helped take my mind off of the hardships of what was going on during research."

Student 42: "[Teaching] is helpful for my depression because, like I am sorry if this is cocky sounding, but I'm really good at teaching and when I go in to teach, it's like, 'I know that this is right."'

$$
\begin{aligned}
& \text { Student 16: "[Teaching] was } \\
& \text { really helpful for my } \\
& \text { depression, because I made } \\
& \text { friends with the other TAs, } \\
& \text { especially during my first } \\
& \text { year as a TA, and we were } \\
& \text { all new." }
\end{aligned}
$$

Student 8: "I have to have the test made by the time class starts on an exam day. I have to make sure that I'm there on time and that I don't go over time, things like that. So just having that kind of strict schedule, I think helped [my depression]."

Student 15: "[Teaching] gave me motivation and kind of like a reason to keep going. I love science, but I love the access to science that I can give to other people."

Student 4: "[Teaching] is a good respite from my research sometimes. It's a different side to being in school."

Student 50: "It's good to feel like an expert in front of this group of undergrads. When you come from maybe a lab, or field experience where you feel like you don't know what you're doing, it can be very positively reinforcing working with undergrads."

Student 28: "I had a co-TA giving a lecture with me and he was a very nice person. So, we became friends. Yeah. It helped [my depression] a little bit."

\footnotetext{
${ }^{\text {a} F o r t y-t h r e e ~ o u t ~ o f ~ t h e ~} 50$ students who participated in the study had experience teaching undergraduates either as a TA or as an instructor of record. We only considered the responses from the TAs with teaching experiences when calculating the percent of students who reported each factor.
} 
TABLE 6. Self-reported ways that depression affected PhD students' research or the student as a researcher

\begin{tabular}{|c|c|c|c|c|}
\hline Theme & Description & $\%(n)(N=50)$ & Example quote & Example quote \\
\hline $\begin{array}{l}\text { Lack of motivation } \\
\text { and productivity }\end{array}$ & $\begin{array}{l}\text { Depression can make students } \\
\text { feel less motivated to do } \\
\text { research, which can result } \\
\text { in a lack of productivity. } \\
\text { This lack of productivity } \\
\text { can range from not being } \\
\text { able to analyze a data set } \\
\text { to not being able to write } \\
\text { and submit a paper. }\end{array}$ & $64(32)$ & $\begin{array}{l}\text { Student 3: "When I'm really } \\
\text { depressed and I'm trying to } \\
\text { do something that's pretty } \\
\text { positive and challenging, } \\
\text { like write a manuscript, it } \\
\text { tends to be really difficult. I } \\
\text { can go from, when I'm not } \\
\text { depressed, banging out } \\
\text { some really good work, and } \\
\text { then when I become } \\
\text { depressed, that definitely } \\
\text { tanks." }\end{array}$ & $\begin{array}{l}\text { Student 35: "[Depression] keeps } \\
\text { me from doing the things } \\
\text { that I want to do, like every } \\
\text { single day and be consistent. } \\
\text { Like reading a paper every } \\
\text { day or writing for an hour } \\
\text { every day and it's just like, I } \\
\text { am so exhausted that I feel } \\
\text { like I can't do that. It } \\
\text { increases procrastination." }\end{array}$ \\
\hline $\begin{array}{l}\text { Low self-esteem or } \\
\text { overly self-critical }\end{array}$ & $\begin{array}{l}\text { Depression can cause students } \\
\text { to doubt their abilities as a } \\
\text { scientist, be self-critical, } \\
\text { internalize failure, take } \\
\text { unnecessary responsibility } \\
\text { for something that did not } \\
\text { work, and be hyperaware } \\
\text { of any issues they may be } \\
\text { having. }\end{array}$ & $58(29)$ & $\begin{array}{l}\text { Student 10: "Sometimes I feel } \\
\text { I'm an imposter. Internally I } \\
\text { know that I have intelli- } \\
\text { gence, but then it's like I } \\
\text { don't know if I can do it. } \\
\text { Everything is harder, and } \\
\text { then my research will } \\
\text { suffer." }\end{array}$ & $\begin{array}{l}\text { Student 19: “[My depression] } \\
\text { brings on this imposter } \\
\text { syndrome. Like, 'What am I } \\
\text { doing in this program?' So, } \\
\text { I'm constantly struggling } \\
\text { and battling those thoughts. } \\
\text { Never feeling that you fit in, } \\
\text { struggling with, 'Are you } \\
\text { good enough? Is what you're } \\
\text { doing good enough? Should } \\
\text { I stay in this program?"' }\end{array}$ \\
\hline $\begin{array}{l}\text { Difficulty focusing } \\
\text { and concentrating }\end{array}$ & $\begin{array}{l}\text { Depression can cause students } \\
\text { to be distracted or } \\
\text { unfocused or to struggle } \\
\text { to pay attention to detail, } \\
\text { which can result in feelings } \\
\text { of frustration and } \\
\text { exhaustion. }\end{array}$ & $28(14)$ & $\begin{array}{l}\text { Student 9: "Because I was going } \\
\text { through kind of a mental } \\
\text { instability, I was unable to } \\
\text { actually focus on what I was } \\
\text { actively doing in lab. I was } \\
\text { kind of like a zombie going } \\
\text { in to work and getting out } \\
\text { every day." }\end{array}$ & $\begin{array}{l}\text { Student 40: "The trouble } \\
\text { concentrating just makes } \\
\text { everything harder when you } \\
\text { just can't seem to sit down } \\
\text { and focus and get things } \\
\text { done. I would say it's made } \\
\text { grad school harder, more } \\
\text { frustrating, and less } \\
\text { enjoyable because I just } \\
\text { constantly feel like I'm } \\
\text { behind and not doing } \\
\text { enough." }\end{array}$ \\
\hline
\end{tabular}

\section{The Effect of Depression on Teaching}

Graduate students described one positive way and two negative ways that depression affected their teaching. Students explained that, because they had experienced depression, they were more compassionate and empathetic toward the undergraduates in their courses. Specifically, they felt they could better understand some of the struggles that undergraduates experience and were sometimes more likely to be flexible or lenient about course requirements and deadlines if an undergraduate was struggling. However, graduate students reported that depression also negatively affected their teaching. Specifically, depression could cause graduate students to feel disconnected or disengaged from undergraduates. It could also cause graduate students to feel as though they had a lack of energy or felt down when teaching. The common self-reported ways that depression affected $\mathrm{PhD}$ students' teaching and example quotes are reported in Table 7 .

\section{DISCUSSION}

Despite the increasing concern about graduate student mental health among those in the scientific community (Pain, 2018; "The Mental Health of PhD Researchers," 2019; Puri, 2019), there is a lack of information about how specific aspects of science $\mathrm{PhD}$ programs affect students with depression. This is the first study to explicitly investigate which particular aspects of research and teaching affect depression among life sciences $\mathrm{PhD}$ students and how depression, in turn, affects graduate students' experiences in research and teaching. Overall, graduate students highlighted factors related to teaching and research that both alleviated and exacerbated their symptoms of depression. Graduate students more commonly brought up ways that research negatively affected their depression, than ways that it positively affected their depression. Conversely, graduate students more commonly mentioned ways that teaching had a positive effect on their depression compared with a negative effect. The requirement and opportunity to teach differs among life sciences graduate programs (Schussler et al., 2015; Shortlidge and Eddy, 2018). As such, future research should investigate whether the amount of teaching one engages in during graduate school is related to levels of graduate student depression. Despite differences in how teaching and research affect student depression, this study unveiled factors that protect against or worsen depressive symptoms. Specifically, four overarching factors affecting graduate student depression 
TABLE 7. Self-reported ways that depression affected PhD students' teaching or the graduate student as an instructor

\begin{tabular}{|c|c|c|c|c|}
\hline Factor & Description & $\%(n)(N=43)^{\mathrm{a}}$ & Example quote & Example quote \\
\hline \multicolumn{5}{|c|}{ Negative effects on depression on graduate student teaching } \\
\hline $\begin{array}{l}\text { Disconnected or disengaged } \\
\text { from undergraduates }\end{array}$ & $\begin{array}{l}\text { Depression can cause } \\
\text { graduate students to feel } \\
\text { disengaged when } \\
\text { teaching or to have } \\
\text { trouble connecting with } \\
\text { undergraduates. }\end{array}$ & $16(7)$ & $\begin{array}{l}\text { Student 18: "[When I have } \\
\text { depression], I can feel } \\
\text { disconnected from the } \\
\text { [undergraduates]. I'll go } \\
\text { to my day of teaching, I } \\
\text { lead these discussion } \\
\text { sections and I'm going } \\
\text { through the motions. I } \\
\text { don't really put my full } \\
\text { heart into it in terms of } \\
\text { going out of my way to } \\
\text { connect with the } \\
\text { [undergraduates] or } \\
\text { being more enthusiastic." }\end{array}$ & $\begin{array}{l}\text { Student 49: "But there were } \\
\text { many days that my } \\
\text { depression, through } \\
\text { various avenues, caused } \\
\text { me to be absentminded } \\
\text { [while teaching]. (...) Just } \\
\text { less attentive and [less] } \\
\text { engaged." }\end{array}$ \\
\hline \multicolumn{5}{|c|}{ Positive effect of depression on graduate student teaching } \\
\hline $\begin{array}{l}\text { Understanding of student } \\
\text { issues }\end{array}$ & $\begin{array}{l}\text { Depression can positively } \\
\text { impact graduate students } \\
\text { as instructors because } \\
\text { they are more under- } \\
\text { standing or sympathetic } \\
\text { to student struggles, } \\
\text { including mental health } \\
\text { issues. }\end{array}$ & $23(10)$ & $\begin{array}{l}\text { Student 16: "[My depression] } \\
\text { maybe makes me a little } \\
\text { more empathetic with the } \\
\text { undergraduates that I } \\
\text { teach. And I know that } \\
\text { since depression is a big } \\
\text { deal for me, it may be as } \\
\text { big deal for them. I'm } \\
\text { able to empathize better } \\
\text { and help people seek out } \\
\text { the right resources if } \\
\text { necessary, and also give } \\
\text { them a leniency that they } \\
\text { need if they can't } \\
\text { accomplish something in } \\
\text { the time it's due because } \\
\text { of their illness." }\end{array}$ & $\begin{array}{l}\text { Student 48: "I think it makes } \\
\text { me more empathetic to the } \\
\text { plights of undergraduate } \\
\text { students, because I know } \\
\text { that they also experience a } \\
\text { lot of these [mental } \\
\text { health] problems, and so I } \\
\text { think it makes me more } \\
\text { sympathetic to their } \\
\text { problems." }\end{array}$ \\
\hline
\end{tabular}

aForty-three out of the 50 students who participated in the study had experience teaching undergraduates either as a TA or as an instructor of record. We only considered the responses from the TAs with teaching experiences when calculating the percent of students who reported each theme.

emerged from the interviews: 1) Structure; 2) Positive and Negative Reinforcement; 3) Failure and Success; 4) Social Support and Isolation. We discuss here how each of these factors may positively and negatively affect graduate student depression.

\section{Structure}

One stark contrast between research and teaching is the amount of structure in each activity. That is, students expressed that research goals are often amorphous, that there are not concrete instructions for what needs to be accomplished, and that there is often no set schedule for when particular tasks need to be accomplished. Conversely, with teaching, graduate students often knew what the goals were (e.g., to help students learn), exactly what they needed to accomplish each week (e.g., what to grade, what to teach), and when and where they needed to show up to teach (e.g., a class meets at a particular time). Graduate students highlighted that a lack of structure, particularly in research, was detrimental for their depression. Their depression often made it difficult for them to feel motivated when there was not a concrete task to accomplish. Major depression can interfere with executive function and cognition, making goal setting and goal achievement particularly difficult 
(Elliott, 1998; Watkins and Brown, 2002). In fact, research has documented that individuals with depression generate less specific goals and less specific explanations for approaching a goal than individuals who do not have depression (Dickson and Moberly, 2013). As such, it may be particularly helpful for students with depression when an activity is structured, relieving the student from the need to articulate specific goals and steps to achieve goals. Students noted that the lack of structure or the flexibility in research was helpful for their depression in one way: It allowed them to better treat their depression. Specifically, students highlighted that they were able to take time to go to therapy or to not go into the lab or to avoid stressful tasks, which may be important for successful recovery from a depressive episode (Judd et al., 2000).

Compared with conducting research, many participants reported that the concrete tasks associated with teaching undergraduates were helpful for their depression. This is supported by literature that illustrates that concrete thinking, as opposed to abstract thinking, can reduce difficulty making decisions in individuals with depression (Dey et al., 2018), presuming that teaching often requires more concrete thinking compared with research, which can be more abstract. Additionally, cognitive-behavioral treatments for depression have demonstrated that developing concrete goals for completing tasks is helpful for individuals with depression (Detweiler-Bedell and Whisman, 2005), which aligns with graduate students' perceptions that having concrete goals for completing teaching tasks was particularly helpful for their depression.

\section{Positive and Negative Reinforcement}

Graduate students reported that the negative reinforcement experienced in research and teaching had a significant negative effect on their depression, while the positive reinforcement students experienced only in teaching had a positive effect. Notably, students did not mention how positive reinforcement affected their depression in the context of research. Based on student interviews, we predict that this is not because they were unaffected by positive reinforcement in research, but because they experienced it so infrequently. Drawing from behavioral theories of depression, the concept of response-contingent positive reinforcement (RCPR; Lewinsohn, 1974; Kanter et al., 2004) helps explain this finding. As summarized by Kanter and colleagues (2004), RCPR describes someone seeking a response and being positively reinforced; for example, graduate students seeking feedback on their research are told that what they have accomplished is impressive. Infrequent RCPR may lead to cognitive symptoms of depression, such as low self-esteem or guilt, resulting in somatic symptoms of depression, such as fatigue and dysphoria (Lewinsohn, 1974; Martell et al., 2001; Manos et al., 2010). RCPR is determined by three factors. 1) How many potential events may be positively reinforcing to an individual. For example, some people may find an undergraduate scoring highly on an exam in a class they are teaching to be reinforcing and others may find that they only feel reinforced when an undergraduate explicitly compliments their teaching. 2) The availability of reinforcing events in the environment. If graduate students' mentors have the ability to provide them with RCPR but are never able to meet with them, these reinforcing events are unavailable to them. 3) The instrumental behavior of an individual. Does the individual exhibit the behavior required to obtain RCPR? If graduate students do not accomplish their research-related tasks on time, they may not receive RCPR from their mentor. If individuals are not positively reinforced for a particular behavior, they may stop exhibiting it, further exacerbating the depressive cycle (Manos et al., 2010). Therefore, the lack of positive reinforcement in research may be particularly damaging to graduate students, because it may discourage them from completing tasks, leading to additional depressive symptoms. Conversely, teaching presents many opportunities for positive reinforcement. Every time graduate students teach, they have the opportunity to receive positive reinforcement from their students or to witness a student's academic accomplishment, such as an undergraduate expressing excitement when they understand a concept. As such, it is not surprising that positive reinforcement was the primary teaching-related factor that graduate students reported helped with their depression. Despite the positive reinforcement of teaching for graduate students with depression, we are not suggesting that graduate students should take on additional teaching loads or that teaching should be viewed as the sole respite for graduate students with depression. Overwhelming students with increased responsibilities may counteract any positive impact that teaching could have on students' depression.

\section{Failure and Success}

Failure and success affected student depression, but only in the context of research; contrary to research, students rarely mentioned concrete metrics for success and failure in teaching. While graduate students highlighted receiving positive or negative reinforcement from undergraduates, they did not relate this to being a "successful" instructor. It is unsurprising that graduate students did not mention failing or succeeding at teaching, given that experts in teaching agree that it is difficult to objectively evaluate quality teaching (d'Apollonia and Abrami, 1997; Kember et al., 2002; Gormally et al., 2014). In fact, the lack of teacher training and knowledge about how to teach effectively negatively affected student depression, because it could cause students to feel unprepared as an instructor. Integrating teacher training into graduate programs has been championed for decades (Torvi, 1994; Tanner and Allen, 2006; Schussler et al., 2015); however, the potential for such training to bolster graduate student mental health is new and should be considered in future research. With regard to graduate students' research, the concept of success and failure was far more concrete; students mentioned failing in terms of failed experiments, research projects, and rejected manuscripts and grant proposals. Successes included accepted manuscripts, funded grant proposals, and concrete progress on significant tasks, such as writing or conducting an experiment that yielded usable data. Failure has been shown to negatively affect depression among undergraduate researchers (Cooper et al., 2020a), who are hypothesized to be inadequately prepared to experience failure in science (Henry et al., 2019). However, it is less clear how well prepared graduate students are to experience failure (Simpson and Maltese, 2017). Drawing from cognitive theories of depression, depression is associated with dysfunctional cognitive schemas or dysfunctional thinking that can lead individuals with depression to have negative thoughts about the world, themselves, and the future and to interpret information more negatively than is actually the case (called 
negative information-processing biases; Beck, 1967; Beck et al., 1979; Gotlib and Krasnoperova, 1998; Maj et al., 2020). Related to failure, individuals with dysfunctional cognitive schemas may harbor beliefs such as if something fails at work (or in graduate research), they are a failure as a person or that a small failure can be as detrimental as a larger failure (Weissman, 1979; Miranda and Persons, 1988). As such, setbacks in research may be particularly difficult for $\mathrm{PhD}$ students with depression. Graduate students in our study also mentioned how failing in research was often out of their control, particularly failure related to experiments and research projects. The extent to which one feels they can control their environment is important for mental health, and lower estimates of control have been hypothesized to be an important factor for depression (Grahek et al., 2019). Therefore, this feeling of being unable to control success in research may further exacerbate student depression, but this would need to be tested. Importantly, these findings do not imply that individuals with depression are unable to cope with failure; they only suggest that individuals perceive that failure in science can exacerbate their depression.

\section{Social Support and Isolation}

Graduate students reported that feelings of isolation in research could worsen their depression. Specifically, they highlighted that it can be difficult for their mental health when their friends outside graduate school cannot relate to their struggles in research and when others in their research group are not working on similar projects. One study of more than 1400 graduate students at a single university found that feeling isolated from fellow graduate students and faculty positively predicted imposter phenomenon (Cohen and McConnell, 2019), defined as the worry that they were fooling others about their abilities and that their fraudulence would be exposed (Clance and Imes, 1978), which is positively correlated with depression among college students (McGregor et al., 2008). Developing a positive lab environment, where undergraduates, graduate students, and postgraduates develop positive relationships, has been shown to positively affect undergraduates (Cooper et al., 2019) and may also positively affect graduate students who experience such feelings of isolation. Graduate students in this study described that both teaching and research had the potential to be a source for relationship development and social support. Students who described positive collaborative relationships in research and teaching felt this had a positive impact on their depression, which aligns with a review of studies in psychiatry concluding that being connected to a large number of people and having individuals who are able to provide emotional support by listening or giving advice is protective against depression (Santini et al., 2015), as well as a study that found that social support is protective against depression, specifically among the graduate population (Charles et al., 2021).

These four factors provide clear targets for graduate programs looking to improve the experiences of students with depression. For example, increasing structure in research could be particularly helpful for graduate students with depression. Ensuring that students have concrete plans to accomplish each week may not only positively impact depression by increasing structure, but ultimately by increasing a student's success in research. Research mentors can also emphasize the role of failure in science, helping students realize that failure is more common than they may perceive. Increasing opportunities for positive reinforcement in teaching and research may be another avenue to improving student mental health. Providing students with appropriate teacher training is a first step to enhancing their teaching skills and potential for positive reinforcement from undergraduate students (Schussler et al., 2015). Additionally, teaching evaluations, a common form of both positive and negative reinforcement, are known to be biased and disadvantage women, People of Color, and those with non-English speaking backgrounds (Fan et al., 2019; Chávez and Mitchell, 2020) and arguably should not be used to assess teaching. In research, mentors can make an effort to provide positive feedback or praise in meetings in addition to critiques. Finally, to provide social support to graduate students with depression, graduate programs could consider creating specific initiatives that are related to supporting the mental health of graduate students in their departments, such as a support group for students to meet and discuss their experiences in graduate school and how those experience pertain to their mental health.

\section{Limitations and Directions for Future Research}

In this study, we chose to only interview students with the identity of interest (depression), as is common with exploratory studies of individuals with underserved, underrepresented, or marginalized identities (e.g. Carlone and Johnson, 2007; Cooper and Brownell, 2016; Barnes et al., 2017, 2021; Downing et al., 2020; Gin et al., 2021; Pfeifer et al., 2021). However, in future studies, it would be beneficial to also examine the experiences of individuals who do not have depression. This would provide information about the extent to which specific aspects of graduate research and teaching are disproportionately beneficial or challenging for students with depression. In this study, we did not explicitly examine whether there was a relationship between students' identities and depression because of the small number of students in particular demographic groups. However, a theme that occurred rather infrequently (but is included in the Supplemental Material) is that discrimination or prejudice in the lab or academia could affect depression, which was reported exclusively by women and People of Color. As such, disaggregating whether gender and race/ethnicity predicts unique factors that exacerbate student depression is an important next step in understanding how to create more equitable and inclusive research and teaching environments for graduate students. Moreover, our sample included a significant number of students from ecology and evolutionary biology $\mathrm{PhD}$ programs, which may limit the generalizability of some findings. It is important to acknowledge potential subdisciplinary differences when considering how research may affect depression. Additionally, some of the factors that affect student depression, such as lack of teaching training and confidence in teaching, may be correlated with time spent in a graduate program. Future quantitative studies would benefit from examining whether the factors that affect student depression depend on the student's subdiscipline and time spent in the graduate program. The primary focus of this study was the relationship between depression and graduate teaching/research. Many of the factors that emerged from the interviews are also associated 
with burnout (Bianchi et al., 2014; Maslach et al., 2001). Burnout and depression are known to be highly related and often difficult to disaggregate (Bianchi et al., 2014). It was beyond the scope and design of this study to disaggregate which factors relate exclusively to the condition of burnout. Additionally, the interviews in this study were collected at a single time point. Thus, we are unable to differentiate between students who had depression before starting graduate school and students who experienced depression after starting graduate school. Future longitudinal studies could explore the effects of students' experiences in research and teaching on their depression over time as well as on long-term outcomes such as persistence in graduate programs, length of time for degree completion, and career trajectory. This study identified a number of factors that graduate programs can address to benefit graduate student mental health, and we hope that future studies design and test interventions designed to improve the experiences of graduate students in teaching and research.

\section{CONCLUSION}

In this interview study of 50 life sciences PhD students with depression, we examined how graduate research and teaching affect students' depressive symptoms. We also explored how depression affected graduate students' teaching and research. We found that graduate students more commonly highlighted ways that research negatively affected their depression and ways that teaching positively affected their depression. Four overarching factors, three of which were related to both teaching and research, were commonly associated with student depression, including the amount of structure provided in research and teaching, failure and success, positive and negative reinforcement, and social connections and isolation. Additionally, graduate students identified depression as having an exclusively negative effect on their research, often hindering motivation, concentration, and self-esteem. However, they did note that depression made them more compassionate teachers, but also could cause them to have low energy or feel disconnected when teaching. This study provides concrete factors that graduate programs can target in hopes of improving the experiences of life sciences $\mathrm{PhD}$ students with depression.

\section{Important Note}

There are resources available if you or someone you know is experiencing depression and want help. Colleges and universities often have crisis hotlines and counseling services designed to provide students, staff, and faculty with treatment for depression. These can often be found by searching the university website. Additionally, there are free $24 / 7$ services such as Crisis Text Line, which allows you to text a trained live crisis counselor (text "CONNECT" to 741741; Text Depression Hotline, 2019), and phone hotlines such as the National Suicide Prevention Lifeline at 1-800-273-8255 (TALK). If you would like to learn more about depression or depression help and resources near you, visit the Anxiety and Depression Association of American website: https://adaa.org (Anxiety and Depression Association of America, 2019) and the Depression and Bipolar Support Alliance: http://dbsalliance.org (Depression and Bipolar Support Alliance, 2019).

\section{ACKNOWLEDGMENTS}

We are incredibly grateful to the 50 graduate students who were willing to share their personal experiences with us. We thank Sara Brownell, Tasneem Mohammed, Carly Busch, Maddie Ostwald, Lauren Neel, and Rachel Scott for their helpful feedback on earlier drafts of this work. L.E.G. was supported by an NSF Graduate Fellowship (DGE-1311230). Any opinions, findings, conclusions, or recommendations expressed in this material are those of the authors and do not necessarily reflect the views of the NSF.

\section{REFERENCES}

American College Health Association. (2014). Graduate/professional reference group report, Spring 2014 (American College Health Association National College Health Assessment II). Retrieved March 15, 2021, from www.acha.org/documents/ncha/NCHA-II_WEB-PAPER_SPRING2014 _GRADUATE_PROFESSIONAL_REFERENCEGROUP_DATAREPORT.pdf

American College Health Association. (2019). Graduate/professional reference group report, Spring 2019 (American College Health Association National College Health Assessment II). Retrieved March 15, 2021, from www.acha org/documents/ncha/NCHA-II_SPRING_2019_GRADUATE_AND _PROFESSIONAL_REFERENCE_GROUP_DATA_REPORT.pdf

American Psychiatric Association. (2013). Diagnostic and statistical manual of mental disorders (5th ed.). Washington, DC: American Psychiatric Publishing.

American Psychiatric Association. (2020). What is depression? Retrieved March 15, 2021, from www.psychiatry.org/patients-families/depression/ what-is-depression

Anxiety and Depression Association of America. (2015). A survey about mental health and suicide in the United States. Retrieved March 15, 2021, from https://adaa.org/sites/default/files/College-Aged_Adults_Survey _Summary-1.14.16.pdf

Anxiety and Depression Association of America. (2019). Retrieved October 1 2019, from https://adaa.org

Barnes, M. E., Truong, J. M., \& Brownell, S. E. (2017). Experiences of Judeo-Christian students in undergraduate biology. CBE-Life Sciences Education, 16(1), ar15.

Barnes, M. E., Maas, S. A., Roberts, J. A., \& Brownell, S. E. (2021). Christianity as a concealable stigmatized identity (CSI) among biology graduate students. CBE-Life Sciences Education, 20(1), ar9.

Beck, A. T. (1967). Depression: Clinical, experimental and theoretical aspects New York: Harper \& Row.

Beck, A. T., Rush, A. J., \& Shaw, B. F. (1979). Cognitive therapy of depression New York, NY: Guilford.

Bianchi, R., Schonfeld, I. S., \& Laurent, E. (2014). Is burnout a depressive disorder? A reexamination with special focus on atypical depression International Journal of Stress Management, 21(4), 307.

Barreira, P., Basilico, M., \& Bolotnyy, V. (2020). Graduate student mental health: Lessons from American economics departments. Working Paper Cambridge, MA: Harvard University. https://scholar.harvard.edu/ bolotnyy/publications/graduate-student-mental-health-lessons-american -economics-departments

Busch, F. N., Rudden, M., \& Shapiro, T. (2016). Psychodynamic treatment of depression. Washington, DC: American Psychiatric Publishing.

Carlone, H. B., \& Johnson, A. (2007). Understanding the science experiences of successful women of color: Science identity as an analytic lens. Journal of Research in Science Teaching, 44(8), 1187-1218.

Carvalho, J., Trent, L. R., \& Hopko, D. R. (2011). The impact of decreased environmental reward in predicting depression severity: Support for behavioral theories of depression. Psychopathology, 44(4), 242-252.

Charles, S. T., Karnaze, M. M., \& Leslie, F. M. (2021). Positive factors related to graduate student mental health. Journal of American College Health, 1-9. https://doi.org/10.1080/07448481.2020.1841207

Charmaz, K. (2006). Constructing grounded theory: A practical guide through qualitative research. Thousand Oaks, CA: Sage.

Chávez, K., \& Mitchell, K. M. (2020). Exploring bias in student evaluations: Gender, race, and ethnicity. PS: Political Science \& Politics, 53(2), 270-274. 
Chirikov, I., Soria, K. M., Horgos, B., \& Jones-White, D. (2020). Undergraduate and graduate students' mental health during the COVID-19 pandemic Oakland, CA: California Digital Library, University of California.

Clance, P. R., \& Imes, S. A. (1978). The imposter phenomenon in high achieving women: Dynamics and therapeutic intervention. Psychotherapy: Theory, Research \& Practice, 15(3), 241.

Cohen, E. D., \& McConnell, W. R. (2019). Fear of fraudulence: Graduate school program environments and the impostor phenomenon. Sociological Quarterly, 60(3), 457-478.

Cooper, K. M., \& Brownell, S. E. (2016). Coming out in class: Challenges and benefits of active learning in a biology classroom for LGBTQIA students. CBE-Life Sciences Education, 15(3), ar37.

Cooper, K. M., Gin, L. E., Akeeh, B., Clark, C. E., Hunter, J. S., Roderick, T. B., ... \& Brownell, S. E. (2019). Factors that predict life sciences student persistence in undergraduate research experiences. PLOS ONE, 14(8). https:// doi.org/10.1371/journal.pone.0220186

Cooper, K. M., Gin, L. E., Barnes, M. E., \& Brownell, S. E. (2020a). An exploratory study of students with depression in undergraduate research experiences. CBE-Life Sciences Education, 19(2), ar19.

Cooper, K. M., Gin, L. E., \& Brownell, S. E. (2020b). Depression as a concealable stigmatized identity: What influences whether students conceal or reveal their depression in undergraduate research experiences? International Journal of STEM Education, 7, 1-18.

d'Apollonia, S., \& Abrami, P. C. (1997). Navigating student ratings of instruction. American Psychologist, 52(11), 1198.

Depression and Bipolar Support Alliance. (2019). Retrieved March 15, 2021, from http://dbsalliance.org

Detweiler-Bedell, J. B., \& Whisman, M. A. (2005). A lesson in assigning homework: Therapist, client, and task characteristics in cognitive therapy for depression. Professional Psychology: Research and Practice, 36(2), 219

Dey, S., Newell, B. R., \& Moulds, M. L. (2018). The relative effects of abstract versus concrete thinking on decision-making in depression. Behaviour Research and Therapy, 110, 11-21.

Dickson, J. M., \& Moberly, N. J. (2013). Reduced specificity of personal goals and explanations for goal attainment in major depression. PLOS ONE 8(5), e64512

Downing, V. R., Cooper, K. M., Cala, J. M., Gin, L. E., \& Brownell, S. E. (2020). Fear of negative evaluation and student anxiety in community college active-learning science courses. CBE-Life Sciences Education, 19(2), $\operatorname{ar} 20$.

Elliott, R. (1998). The neuropsychological profile in unipolar depression. Trends in Cognitive Sciences, 2(11), 447-454

Evans, T. M., Bira, L., Gastelum, J. B., Weiss, L. T., \& Vanderford, N. L. (2018). Evidence for a mental health crisis in graduate education. Nature Biotechnology, 36(3), 282.

Fan, Y., Shepherd, L. J., Slavich, E., Waters, D., Stone, M., Abel, R., \& Johnston, E. L. (2019). Gender and cultural bias in student evaluations: Why representation matters. PLOS ONE, 14(2), e0209749.

Flaherty, C. (2018). New study says graduate students' mental health is a "crisis." Inside Higher Ed. Retrieved March 15, 2021, from www insidehighered.com/news/2018/03/06/new-study-says-graduate -students-mental-health-crisis

Gin, L. E., Guerrero, F. A., Brownell, S. E., \& Cooper, K. M. (2021). COVID-19 and undergraduates with disabilities: Challenges resulting from the rapid transition to online course delivery for students with disabilities in undergraduate STEM at large-enrollment institutions. CBE-Life Sciences Education, 20(3), ar36.

Glesne, C., \& Peshkin, A. (1992). Becoming qualitative researchers: An introduction. London, UK: Longman.

Gormally, C., Evans, M., \& Brickman, P. (2014). Feedback about teaching in higher ed: Neglected opportunities to promote change. CBE-Life Sciences Education, 13(2), 187-199

Gotlib, I. H., \& Krasnoperova, E. (1998). Biased information processing as a vulnerability factor for depression. Behavior Therapy, 29(4), 603-617.

Grahek, I., Shenhav, A., Musslick, S., Krebs, R. M., \& Koster, E. H. (2019). Motivation and cognitive control in depression. Neuroscience \& Biobehavioral Reviews, 102, 371-381.
Helmers, K. F., Danoff, D., Steinert, Y., Leyton, M., \& Young, S. N. (1997). Stress and depressed mood in medical students, law students, and graduate students at McGill University. Academic Medicine, 72(8), 708-714.

Henry, M. A., Shorter, S., Charkoudian, L., Heemstra, J. M., \& Corwin, L. A. (2019). FAIL is not a four-letter word: A theoretical framework for exploring undergraduate students' approaches to academic challenge and responses to failure in STEM learning environments. CBE-Life Sciences Education, 18(1), ar11.

Hish, A. J., Nagy, G. A., Fang, C. M., Kelley, L., Nicchitta, C. V., Dzirasa, K., \& Rosenthal, M. Z. (2019). Applying the stress process model to stressburnout and stress-depression relationships in biomedical doctoral students: A cross-sectional pilot study. CBE-Life Sciences Education, 18(4), ar51.

Howell, E., \& McFeeters, J. (2008). Children's mental health care: Differences by race/ethnicity in urban/rural areas. Journal of Health Care for the Poor and Underserved, 19(1), 237-247.

Jones-White, D. R., Soria, K. M., Tower, E. K., \& Horner, O. G. (2020). Factors associated with anxiety and depression among US doctoral students: Evidence from the gradSERU survey. Journal of American College Health, 1-12. https://doi.org/10.1080/07448481.2020.1865975

Judd, L. L., Paulus, M. J., Schettler, P. J., Akiskal, H. S., Endicott, J., Leon, A. C. ... \& Keller, M. B. (2000). Does incomplete recovery from first lifetime major depressive episode herald a chronic course of illness? American Journal of Psychiatry, 157(9), 1501-1504.

Kanter, J. W., Callaghan, G. M., Landes, S. J., Busch, A. M., \& Brown, K. R. (2004). Behavior analytic conceptualization and treatment of depression: Traditional models and recent advances. Behavior Analyst Today, 5(3), 255.

Kataoka, S. H., Zhang, L., \& Wells, K. B. (2002). Unmet need for mental health care among US children: Variation by ethnicity and insurance status. American Journal of Psychiatry, 159(9), 1548-1555

Kember, D., Leung, D. Y., \& Kwan, K. (2002). Does the use of student feedback questionnaires improve the overall quality of teaching? Assessment $\&$ Evaluation in Higher Education, 27(5), 411-425.

Landis, J. R., \& Koch, G. G. (1977). "An application of hierarchical kappa-type statistics in the assessment of majority agreement among multiple observers. Biometrics, 363-374.

Leahy, R. (2002). Clinical advances in cognitive psychotherapy: Theory and application. New York, NY: Springer.

Levecque, K., Anseel, F., De Beuckelaer, A., Van der Heyden, J., \& Gisle, L. (2017). Work organization and mental health problems in PhD students. Research Policy, 46(4), 868-879.

Lewinsohn, P. M. (1974). The psychology of depression: Contemporary theory and research. Sydney, Australia: Halsted Press.

Lipson, S. K., Lattie, E. G., \& Eisenberg, D. (2019). Increased rates of mental health service utilization by US college students: 10-year population-level trends (2007-2017). Psychiatric Services, 70(1), 60-63.

Liu, C., Wang, L., Qi, R., Wang, W., Jia, S., Shang, D., ... \& Yan, S. (2019). Prevalence and associated factors of depression and anxiety among doctoral students: The mediating effect of mentoring relationships on the association between research self-efficacy and depression/anxiety. Psychology Research and Behavior Management, 12, 195.

Maj, M., Stein, D. J., Parker, G., Zimmerman, M., Fava, G. A., De Hert, M., ... \& Wittchen, H.-U. (2020). The clinical characterization of the adult patient with depression aimed at personalization of management. World Psychiatry, 19(3), 269-293.

Manos, R. C., Kanter, J. W., \& Busch, A. M. (2010). A critical review of assessment strategies to measure the behavioral activation model of depression. Clinical Psychology Review, 30(5), 547-561.

Martell, C. R., Addis, M. E., \& Jacobson, N. S. (2001). Depression in context: Strategies for guided action. New York: Norton.

Maslach, C., Schaufeli, W. B., \& Leiter, M. P. (2001). Job burnout. Annual Review of Psychology, 52(1), 397-422.

McGregor, L. N., Gee, D. E., \& Posey, K. E. (2008). I feel like a fraud and it depresses me: The relation between the imposter phenomenon and depression. Social Behavior and Personality: An International Journal, 36(1), $43-48$. 
Mcleod, S. A. (2015). Psychological Theories of Depression. Simply Psychology, Retrieved March 15, 2021, from https://www.simplypsychology.org/ depression.html

Miranda, J., \& Persons, J. B. (1988). Dysfunctional attitudes are mood-state dependent. Journal of Abnormal Psychology, 97(1), 76.

The mental health of $\mathrm{PhD}$ researchers demands urgent attention [Editorial]. (2019). Nature, 575(7782), 257-258. https://doi.org/10.1038/d41586 -019-03489-1

Pain, E. (2018, March 6). Graduate students need more mental health support, study highlights. Science. Retrieved March 15, 2021, from www sciencemag.org/careers/2018/03/graduate-students-need-more -mental-health-support-new-study-highlights

Peluso, D. L., Carleton, R. N., \& Asmundson, G. J. (2011). Depression symptoms in Canadian psychology graduate students: Do research productivity, funding, and the academic advisory relationship play a role? Canadian Journal of Behavioural Science/Revue Canadienne des Sciences du Comportement, 43(2), 119.

Pfeifer, M. A., Reiter, E. M., Cordero, J. J., \& Stanton, J. D. (2021). Inside and out: Factors that support and hinder the self-advocacy of undergraduates with ADHD and/or specific learning disabilities in STEM. CBE-Life Sciences Education, 20(2), ar17.

Puri, P. (2019). The emotional toll of graduate school. Scientific American Blog Network. Retrieved March 15, 2021, from https://blogs .scientificamerican.com/observations/the-emotional-toll-of-graduate -school/

Ramnerö, J., Folke, F., \& Kanter, J. W. (2016). A learning theory account of depression. Scandinavian Journal of Psychology, 57(1), 73-82.

Saldaña, J. (2015). The coding manual for qualitative researchers. Thousand Oaks, CA: Sage.

Santiago, C. D., Kaltman, S., \& Miranda, J. (2013). Poverty and mental health: How do low-income adults and children fare in psychotherapy? Journal of Clinical Psychology, 69(2), 115-126.

Santini, Z. I., Koyanagi, A., Tyrovolas, S., Mason, C., \& Haro, J. M. (2015). The association between social relationships and depression: A systematic review. Journal of Affective Disorders, 175, 53-65.

Schmidt, S. L., \& Tolentino, J. C. (2018). DSM-5 criteria and depression severity: Implications for clinical practice. Frontiers in Psychiatry, 9, 450
Schussler, E. E., Read, Q., Marbach-Ad, G., Miller, K., \& Ferzli, M. (2015) Preparing biology graduate teaching assistants for their roles as instructors: An assessment of institutional approaches. CBE-Life Sciences Education, 14(3), ar31.

Shortlidge, E. E., \& Eddy, S. L. (2018). The trade-off between graduate student research and teaching: A myth? PLOS ONE, 13(6), e0199576.

Simpson, A., \& Maltese, A. (2017). "Failure is a major component of learning anything": The role of failure in the development of STEM professionals. Journal of Science Education and Technology, 26(2), 223-237.

Tanner, K., \& Allen, D. (2006). Approaches to biology teaching and learning: On integrating pedagogical training into the graduate experiences of future science faculty. CBE-Life Sciences Education, 5(1), 1-6.

Text Depression Hotline. (2019). Crisis text line. Retrieved March 15, 2021 from www.crisistextline.org/depression

Torvi, D. A. (1994). Engineering graduate teaching assistant instructional programs: Training tomorrow's faculty members. Journal of Engineering Education, 83(4), 376-382.

Trenor, J. M., Miller, M. K., \& Gipson, K. G. (2011). Utilization of a think-aloud protocol to cognitively validate a survey instrument identifying social capital resources of engineering undergraduates. Vancouver, BC: American Society for Engineering Education.

U.S. News \& World Report: News, Rankings and Analysis on Politics, Education, Healthcare and More. (2019). Retrieved October 1, 2019, from https://www.usnews.com/best-graduate-schools/top-science -schools/biological-sciences-rankings

Watkins, E., \& Brown, R. G. (2002). Rumination and executive function in depression: An experimental study. Journal of Neurology, Neurosurgery \& Psychiatry, 72(3), 400-402.

Weissman, A. (1979). Dysfunctional Attitude Scale (DAS). Acceptance and Commitment Therapy. Measures Package, 54-56. http://www integrativehealthpartners.org/downloads/

Woolston, C. (2017). Graduate survey: A love-hurt relationship. Nature 550(7677), 549-552

Woolston, C. (2019a, August 30). A better future for graduate-student mental health. Nature. https://doi.org/10.1038/d41586-019-02584-7

Woolston, C. (2019b). PhDs: The tortuous truth. Nature, 575(7782), $403-$ 406. https://doi.org/10.1038/d41586-019-03459-7 